\title{
Islands of felicity? - The effect of land cover changes in and around protected areas: a case study of Bach $\mathrm{Ma}$ National Park, Vietnam
}

\author{
Matusch, Tobias \\ Department of Cartography and GIS, Institute of Geography and Geology, University of Greifswald, Germany \\ Email address: \\ Tobias.Matusch@uni-greifswald.de \\ To cite this article: \\ Matusch, Tobias. Islands of Felicity? - The Effect of Land Cover Changes in and around Protected Areas: A Case Study of Bach Ma \\ National Park, Vietnam. American Journal of Environmental Protection. Vol. 3, No. 3, 2014, pp. 152-161. \\ doi: 10.11648/j.ajep.20140303.17
}

\begin{abstract}
In recent decades, Vietnam's network of protected areas experienced extensive growth. More than 160 terrestrial and marine protected areas (approximately 2.2 million ha) associated with remarkable reforestation demonstrate major changes within environmental policies. Nevertheless, the degradation of the existing natural forest communities, the associated loss of species and decreasing resilience suggest that Vietnam has still not reached a satisfactory point of conserving these natural habitats. The current study presents an impressive example of land cover change over a period of approximately 40 years at the Bach Ma National Park. Deforestation and degradation processes are a result of illegal activities and land use changes, a consequence of the increasing population. However, land use conflicts often occur outside of protected areas where land cover changes are concentrated and accelerated.
\end{abstract}

Keywords: Deforestation, Forest Degradation, Buffer Zone Management, Remote Sensing, Asia, Vietnam

\section{Introduction}

Nature conservation activities began well before the late 19th and 20th centuries. Early populations suspected that certain species and habitats were more crucial than others. Nearly 700 years ago, certain bird species were protected to avoid the plagues from bugs and insects. Exactly 300 years ago, Carl von Carlowitz introduced the idea of sustainable forest management in his book "Sylvicultura oeconomica" [1]. Modern protected areas, such as Yellowstone National Park (the first national park), are milestones in nature conservation $[2,3]$.

A changing balance of power between humans and nature is evident. It is common for people to protect and conserve natural heritages for their own well-being. In the 20th century, the number of protected areas substantially increased. At the end of 2011, the world database on protected areas (WDPA), run by the United Nations Environment Programme (UNEP) World Conservation Monitoring Centre (WCMC), contains more than 157,000 protected areas (for protected areas with year of designation) worldwide with a total size of more than $24 \mathrm{Mkm}^{2}$. Therefore, nearly $11 \%$ of the earth's surface and $2.3 \%$ of the marine surface are protected areas [4]. When examining related inaccuracies and out-of-date information, we notice that, behind the goals and desires of protection acts, is a large uncertainty with regard to overcrowding. Overlapping areas and various types of protected areas increase the complexity of understanding the necessary amount and coverage of protected areas. Additionally, it is difficult to deny that failures are imminent if these inaccuracies are extrapolated to more detailed information [2,5]. The most important classification of protected areas is based on an International Union for Conservation of Nature (IUCN) system with six different categories. Category Ia (strict nature reserves) and $\mathrm{Ib}$ (wilderness areas) are the most restricted classes, whereas category II (national parks) represents the most famous category, containing the most famous locations. Numerous protected areas are also surrounded by buffer zones which help reduce negative outside influences. However, several disturbing factors decrease the influence of protected areas: small budgets, restricted enforcement rights, insufficient personnel and equipment infrastructure, lack of awareness and mismanagement. The utilization of remote sensing and geo-information-systems (GIS) for monitoring the achievements and consequences of protected areas are widely implemented. Important approaches can be found 
within the scientific literature [6-9] and environmental management and biodiversity conservation journals $[2,10]$.

\section{The System of Protected Areas in Vietnam}

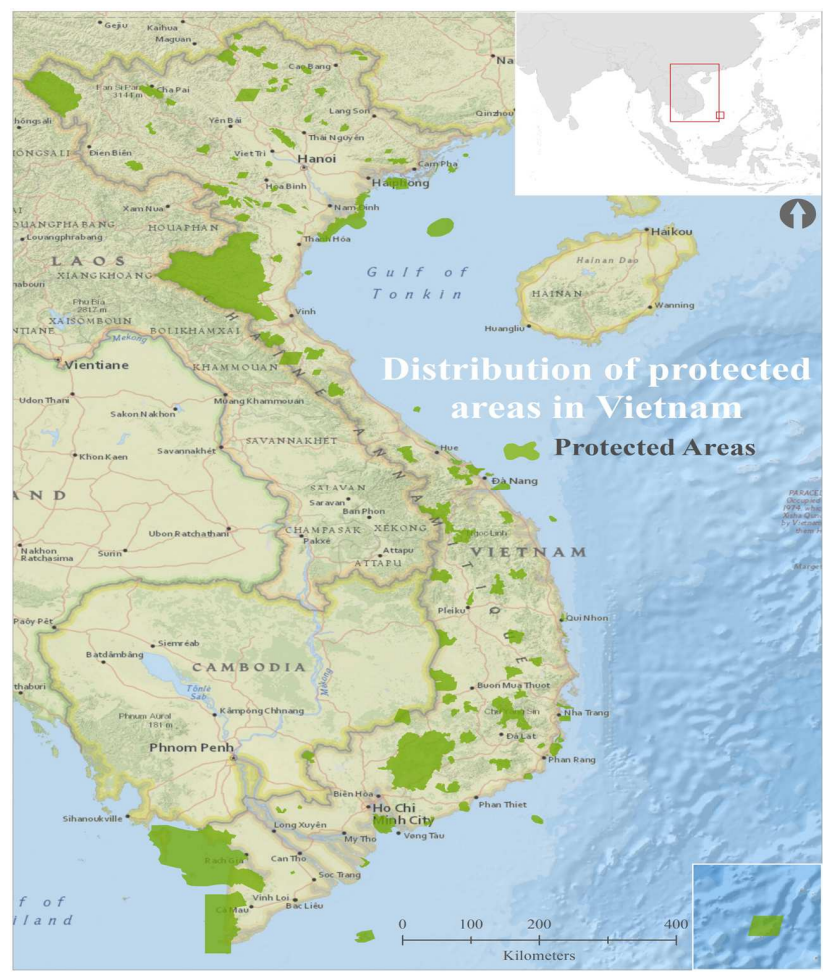

Figure 1. The network of protected areas in Vietnam (data source: World Database on Protected Areas, 2013)

In the second half of the twentieth century the network of protected areas increased rapidly in Vietnam. The reasons for the late development are economic priorities and several internal and external political difficulties (e.g., the Vietnam War from 1964 to 1975). However, the first national park (Cuc Phuong) was declared in 1962 [11,12]. Between 1962 and 1976, 48 additional areas were designated under the pseudonym "Special Use Forests". After the war, additional protected areas were established (e.g., Cat Tien and Cat Ba National Park), along with various monitoring and reporting activities [13]. In the following years, several governmental decisions increased the amount and size of these Special Use Forests to 93, totaling nearly 1 Mha in 1991. Vietnam also ratified several international agreements, such as those from like the RAMSAR convention in 1988 and the Convention on Biological Diversity (CBD) in 1994 [12]. These achievements were accompanied by large deforestation and degradation processes over the entire country [14]. Based on information from Birdlife International from 2012, the current number of protected areas in Vietnam is 164, consisting of 30 national parks, 58 nature reserves, 11 species conservation areas, 45 landscape protection areas, and 20 special use forest areas. In summary, there are nearly 2.2Mha protected, covering approximately $6.6 \%$ of the nation's land surface. These areas are largely composed of forests $(\sim 88 \%)$, whereas water bodies are underrepresented at $\sim 3 \%[15,16]$. However, we observe slightly different results when taking the WDPA data into account (Fig. 1).

In 1990, only $3 \%$ of all terrestrial and marine areas were protected $(4.56 \%$ terrestrial and $0.31 \%$ marine $)$, where the marine water bodies were defined as the 12 nautical miles to the coastline. This area has increased to $4.72 \%(6.45 \%$ terrestrial and $1.73 \%$ marine) in 2012 [4]. Despite these encouraging findings, numerous protected areas facing serious problems, such as insufficient budgets, incapable employees, and a lack of law enforcement.

\section{Bach Ma National Park}

Bach Ma National Park (BMNP) was designated in 1991 as part of the decision No. 214-CT by the ministry of forest [17]. The major objective was the conservation of the only remaining green transects ranging from the southeastern sea to the Annamite mountain ranges adjacent to the border of Lao PDR [18]. At the time, the national park (22,031ha) belonged entirely to the Thua Thien Hue province. Based on decision 01/QD-TTg from 2008, the size of Bach Ma was extended to $37,487 \mathrm{ha}$ and distributed as 12,064.8ha of restricted areas, 5,188.2ha of administrative areas, and 20,246ha of ecological recovery areas [19]. This opportunistic move was based on two facts. First, the goal was to place additional regions under conservation protection due to significant human impacts closely connected with illegal activities. Secondly, the extension zone is located in the southwest of the original area and partly belongs to the Quang Nam province. Based on this administrative overlap, BMNP is still under national administration, resulting in a much higher financial budget and better equipment. BMNP hosts northern and southern flora and fauna species. Due to this bio-geographical border, Bach $\mathrm{Ma}$ is considered an important biodiversity hotspot. Approximately $19 \%$ of Vietnam's plant species occur in only $0.12 \%$ of the country's territory. The annual precipitation of $3,000-3,500 \mathrm{~mm} / \mathrm{a}$ (up to nearly $8,000 \mathrm{~mm} / \mathrm{a}$ ) maintains the evergreen tropical monsoon forest below the $900 \mathrm{~m}$ elevation and the montane evergreen subtropical monsoon forest above $900 \mathrm{~m}[20,21]$.

Several sections of the national park are surrounded by two buffer zones in the South and Northwest (Fig. 2). With a combined size of 57,482ha, the buffer zones provide a home for approximately 79,000 people [19]. Within the last five decades, the population development was quite unstable. Compared to the fertile delta regions, the highlands were often neglected and possessed a much lower population density [22]. After 1975, there was a massive population growth due to natural population increases and migration activities. Additionally, newly established economic zones, resettlement programs, and the extension of cropland were further driving forces. Around BMNP, the population density increased from 44 inhabitants $/ \mathrm{km}^{2}$ in 1976 to 74 inhabitants $/ \mathrm{km}^{2}$ in 1985. However, after the Doi Moi 
reforms in 1986, the low income levels within the highlands forced people to move back to economically stronger regions. Nevertheless, the number of inhabitants within the buffer zones has increased since 1990 (64 people $/ \mathrm{km}^{2}$ to 69 people $/ \mathrm{km}^{2}$ in 2000) [23].

The centers of settlements around BMNP are west of the Nam Dong district and north of the Phu Loc district. According to official information, nobody is living in BMNP as of 2008. Currently, the most crucial problems are illegal exploitations of timber and non-timber forest products (NTFP). As a consequence, the forest is degraded and especially illegal hunting activities of local people in remote areas threaten the wildlife stock [19].

\section{Methodology}

Remote sensing and GIS technologies are widely used for the monitoring of protected areas and associated biodiversity globally. The use of robust, repeatable and consistent methodologies that cover large areas offers major advantages [24-26]. The land cover development of BMNP and surrounding areas were analyzed with a Landsat time series from 1973 to 2010 . The first image was from Landsat $3 \mathrm{MSS}$ with an $80 \mathrm{~m}$ spatial resolution. All other images were from Landsat 5 TM or Landsat 7 ETM+. Table 1 presents a list of images used in this study. The major objective was to find a robust, yet easy-to-handle classification procedures are necessary where minimal ground truth data are available. Typically, the availability of reliable ground truth data sources is highly limited in backward land cover assessments [27,28].

After the downloading procedure, an expedient and straightforward Dark Object Subtraction (DOS) method was used to remove atmospheric scattering [29,30]. To improve the initial results, all Landsat scenes were radiometrically normalized based on a master scene from 2003, which was chosen due to its robust radiometric characteristics. The procedure is based on pseudo-invariant features [31] that are statistically and automatically selected between the pixels of the reference and normalized images [32,33]. With respect to intra-seasonal phenology changes, clouds were detected, masked with associated shadows and replaced with the aid of other images of the same area at different times [34].

After the preprocessing steps, redundancies in the images were reduced via principal component analysis [35]. Additionally, the normalized difference vegetation index (NDVI) [36,37] was calculated and a tasseled cap transformation was performed. These brightness, greenness and wetness indices are widely used with Landsat images $[38,39]$.

Table 1. List of Landsat images used for classification

\begin{tabular}{|c|c|c|c|}
\hline Number & Satellite sensor & Pixel size (in m) & Acquisition date \\
\hline \multirow{3}{*}{1} & \multirow{3}{*}{ Landsat MSS } & \multirow{3}{*}{80} & 26/05/1973 \\
\hline & & & 11/09/1973* \\
\hline & & & $24 / 07 / 1979$ \\
\hline \multirow[t]{2}{*}{2} & \multirow[t]{2}{*}{ Landsat TM } & \multirow[t]{2}{*}{30} & 17/02/1989* \\
\hline & & & $09 / 01 / 2000$ \\
\hline \multirow[t]{2}{*}{3} & \multirow[t]{2}{*}{ Landsat ETM+ } & \multirow[t]{2}{*}{30} & $05 / 10 / 2000$ \\
\hline & & & $06 / 11 / 2000^{*}$ \\
\hline \multirow{2}{*}{4} & \multirow{2}{*}{ Landsat ETM+ } & \multirow{2}{*}{30} & $13 / 02 / 2002$ \\
\hline & & & $02 / 04 / 2002 *$ \\
\hline \multirow{3}{*}{5} & \multirow{3}{*}{ Landsat ETM+ } & \multirow{3}{*}{30} & $31 / 01 / 2003$ \\
\hline & & & $04 / 03 / 2003$ \\
\hline & & & $21 / 04 / 2003 *$ \\
\hline \multirow{2}{*}{6} & \multirow{2}{*}{ Landsat TM } & \multirow{2}{*}{30} & $04 / 05 / 2005^{*}$ \\
\hline & & & $08 / 06 / 2006$ \\
\hline \multirow{2}{*}{7} & \multirow{2}{*}{ Landsat TM } & \multirow{2}{*}{30} & $11 / 02 / 2010$ \\
\hline & & & 05/07/2010* \\
\hline
\end{tabular}

* Basic image with lowest cloud cover / best radiometric properties

Two additional texture bands were computed based on the variance of the original band $2(0.52-0.60 \mu \mathrm{m})$ and the original band $3(0.63-0.69 \mu \mathrm{m})$, each containing information of the arrangement of barren and artificial landscape elements and vegetation, respectively [40,41]. Finally, ASTER GDEM Version 2 was integrated with a spatial resolution of $30 \mathrm{~m}$ [42].

All eleven bands were stacked together and passed through two ISODATA classification loops. The first ISODATA classification was used for a general land cover classification of clouds, shadows, water, forest, urban areas, pasture, cropland, wetland, barren areas, and unclassified pixels. Subsequently, the results from the previous step were masked and traced back into the second ISODATA classification loop. In a variety of cases, separate misclassifications from the first classification loop could be eliminated. The outcome of this procedure was a finer and more precise classification with an overall accuracy of 84-90\% (Table 2). Therefore, the areas were relatively easy and more accurate to distinguish and could be further classified (e.g., dense, medium, and sparse forest). 
Table 2. The accuracy assessment (producer accuracy)

\begin{tabular}{|c|c|c|c|c|c|c|c|c|c|c|c|c|c|c|}
\hline Year & $\begin{array}{c}\text { Overall } \\
\text { Accuracy }\end{array}$ & Карра & Water & $\begin{array}{l}\text { Dense } \\
\text { Forest } \\
\end{array}$ & $\begin{array}{c}\text { Medium } \\
\text { Forest }\end{array}$ & $\begin{array}{l}\text { Sparse } \\
\text { Forest }\end{array}$ & $\begin{array}{c}\text { Barren } \\
\text { Land }\end{array}$ & $\begin{array}{l}\text { Dense } \\
\text { Urban }\end{array}$ & $\begin{array}{c}\text { Medium } \\
\text { Urban }\end{array}$ & $\begin{array}{l}\text { Sparse } \\
\text { Urban }\end{array}$ & Wetlands & Cropland & Pasture & $\begin{array}{c}\text { Pasture / } \\
\text { Urban }\end{array}$ \\
\hline 1973 & 84.460 & 0.804 & 100.00 & 97.38 & 59.71 & 86.93 & 100.00 & 63.64 & 62.50 & 39.53 & 42.67 & 71.57 & 75.20 & 82.39 \\
\hline 1989 & 85.382 & 0.818 & 99.84 & 98.19 & 66.58 & 84.13 & 100.00 & 20.83 & 40.74 & 59.14 & 60.38 & 95.65 & 88.49 & 85.52 \\
\hline 2000 & 87.830 & 0.852 & 100.00 & 96.87 & 80.56 & 86.08 & 100.00 & 22.86 & 30.00 & 56.10 & 43.75 & 53.33 & 87.85 & 85.25 \\
\hline 2002 & 87.384 & 0.847 & 100.00 & 97.12 & 85.14 & 85.25 & 99.58 & 64.77 & 42.86 & 60.98 & 37.84 & 100.00 & 67.23 & 80.45 \\
\hline 2003 & 90.008 & 0.879 & 99.90 & 96.81 & 82.12 & 86.92 & 100.00 & 84.11 & 39.58 & 76.15 & 49.28 & 98.89 & 93.00 & 84.89 \\
\hline 2005 & 88.656 & 0.863 & 99.62 & 93.14 & 85.24 & 89.81 & 98.68 & 76.06 & 70.45 & 61.29 & 44.62 & 96.36 & 84.41 & 67.84 \\
\hline 2010 & 88.228 & 0.858 & 99.72 & 94.97 & 82.06 & 88.73 & 99.54 & 78.57 & 42.86 & 75.14 & 38.89 & 96.00 & 80.69 & 82.86 \\
\hline
\end{tabular}

\section{Land Cover Change from 1973 to 2010}

The selected study area allows for several comparisons of the land cover development from 1973 to 2010 within regions of BMNP and adjacent areas. Based on the dissimilar progress, five different regions were distinguished (Fig. 2 and Table 3). The first region is BMNP with its current configuration. The second region contains both official buffer zones. Additionally, an artificial buffer of $10 \mathrm{~km}$ around the current BMNP was created. Finally, the former shape of the national park and the extension zone, which was added in 2008, were defined as regions four and five, respectively. Furthermore, differentiating between the change and composition of forest cover and development in all other land cover classes helps facilitate a better understanding of the conditions. By analyzing the forest cover in general, we can distinguish between BMNP and adjacent areas.

In 1973 the former shape, the future extension area and consequently the current BMNP were almost fully covered by forest. The two buffer zones and the artificial buffer were $80 \%$ covered by forests. This bisection of forest cover was generally stable during the entire time series. However, in both sections, the forest cover remarkably decreased between 1973 and 2000. Subsequent to this forest loss, all regions exhibit a slight increase until 2005, followed by a slight decrease of forest cover from 2005 to 2010 . However, not only the amount of forest cover but also the composition of the forest was considerably different between the regions.

Table 3. The distinct regions with valid time and size

\begin{tabular}{clcc}
\hline Type of region & Name & Validity & Area (in hectare) \\
\hline Region 1 & Bach Ma National Park & Since 2008 & 37,487 \\
Region 2 & Official BMNP buffer zones & Since 2008 \\
Region 3 & Artificial buffer zone of 10km & Artificial \\
Region 4 & Former BMNP & $1991-2008$ \\
Region 5 & BMNP extension zone & Since 2008 \\
\hline
\end{tabular}

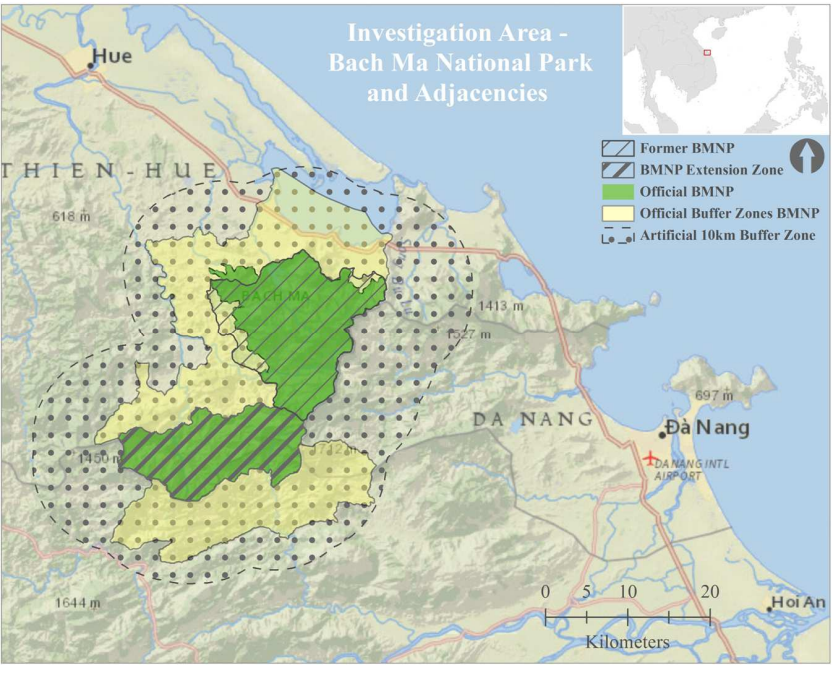

Figure 2. The survey regions within and around BMNP.
Within BMNP, $70 \%$ or $75 \%$ of the forests were dense in 1973. In the adjacent areas, approximately $50 \%$ of the forests can be described as dense. Until the year 2000, the amount of dense forest was decreasing in all regions except the extension zone. Here, the dense forest cover was nearly stable between 1973 and 2000. However, between 2000 and 2005 approximately $15 \%$ of the dense forest cover disappeared within the extension zone. After 2005, the dense forest cover was recovering on a small scale, not only within the extension zone but also within the two buffer zones. Nevertheless, during these 37 years, BMNP lost approximately $27 \%$ of all dense forest; over $50 \%$ of the dense forest was lost within the buffer zones. A significant growth was documented for the medium forest in all regions. In 1973, the amount of medium forest was considerably low, ranging between $16.5 \%$ and $18.5 \%$. A division between BMNP and adjacent areas was not recognizable. The amount of medium forest was generally stable between 1973 and 
2000 with only a small decrease within the former BMNP area and a small increase within the new extension zone. After 2000, a considerable growth was observed in all regions until 2003. Particularly, the excessive increase within the extension zone could be a result of a possible misclassification. After a rapid increase from 2000 to 2003 within the buffer zones and extension area, the medium forest cover was mostly stable. Within the BMNP regions, the medium forest patches rapidly increased until 2005, then again declined considerably. By examining the sparse forest development, a slight bisection between the BMNP regions and the adjacent regions was identified. The overall area of sparse forest minimally declined from 1973 to 1989 within the extension area. In all other regions, an extensive growth was documented. This considerable increasing trend was only interrupted in 2003. This event was correlated with the large increase in medium forests in all regions. Despite a missing indication within the accuracy assessment, both of the observed developments are based on a misclassification between the medium and sparse forest cover in 2003. However, the increase in the sparse forest continued between 2003 and 2010, especially within the BMNP regions. While the area of the sparse forest considerably increased within the buffer zones from 2003 to 2005, a slight declining trend has been documented since 2005. Compared with the forest and with respect to the high coverage, other land cover classes show only slight changes.

Table 4. The forest cover within the five distinguished regions (percentage)

\begin{tabular}{cccccc}
\hline Year & BMNP & Former BMNP & BMNP extension zone & Official BMNP buffer zones & Artificial 10km buffer zone \\
\hline 1973 & 99.14 & 98.26 & 99.45 & 78.63 & 80.64 \\
1989 & 97.95 & 94.26 & 99.76 & 68.71 & 72.03 \\
2000 & 93.74 & 89.06 & 97.31 & 61.01 & 65.39 \\
2002 & 95.90 & 93.99 & 97.37 & 69.02 & 73.10 \\
2003 & 97.65 & 95.09 & 99.13 & 66.24 & 70.11 \\
2005 & 98.44 & 95.89 & 99.83 & 68.52 & 72.58 \\
2010 & 97.56 & 93.78 & 99.68 & 67.58 & 72.11 \\
\hline
\end{tabular}

Nevertheless, they illustrate important transformations and the bisection between BMNP and the adjacent areas. Considering the expanse of water, a mostly stable coverage is observed. Based on the large extent of the Cầu Hai bay, the extent of the water is approximately $10 \%$ and $7 \%$ within buffer zones one and two, respectively. The abrupt increase of the water cover within BMNP is caused by the Hồ Truồi Lake, an artificial reservoir built in 1997. Other small water bodies are difficult to detect due to the coarse spatial resolution of the Landsat satellite images.

Despite a careful selection of Landsat images and their phenological phases, rice fields were detected in different stages of their growth. Additionally, pasture areas possessed considerable variability between the analyzed years. Significant fluctuations were detected, and the accuracy assessment indicates significant misclassifications in 1973 and 2000 for cropland and in 1973 and 2002 for pasture land. Merging both classes together, a slight increase in the total area was observed. The bisection between BMNP and the adjacent areas is not surprising. In 2003, the buffer zones reached their peak with $15 \%$ pasture and cropland cover, whereas BMNP possessed $4.1 \%$ and $6.7 \%$, respectively, of the former area of the national park in 2000.

A stable increase of urban areas in the buffer zones was observed in all years except 2000. Based on the documented population development this increase was expected. Meanwhile, small urban areas within the national park were almost completely removed. The accuracy matrix suggests a large misclassification for all types of urban areas. These inaccuracies are mostly based on the small extent of urban areas in earlier years and the scattered distribution. According to the low spatial resolution, it is not feasible to detect reliable testing areas for the accuracy assessment. Other land cover classes can generally be neglected due to the small area they encompass. The barren land, particularly in the buffer zones, slightly increased (up to 1\%) until 2000, with almost no trace within BMNP.

The most important regions, BMNP (region one) and the original buffer zones (region two), are analyzed further to reconstruct past developments in relation to different elevations. In general, both regions feature the same land cover change since 1973, but with dissimilar intensities and temporal variations. Considering that within BMNP, a remarkable curve is only observable for the dense forest in 1973. In very flat areas with elevations ranging 0 to $200 \mathrm{~m}$, the coverage is nearly $46 \%$. At ground levels of $801 \mathrm{~m}$ to $1,000 \mathrm{~m}$, the coverage of the dense forest reaches its maximum at $88 \%$. With increasing height, the coverage starts to decrease significantly. The medium and sparse forest sections were more important at very low and very high elevations. Describing the same curve for the year 2010, the coverage of dense forest almost disappeared (5\%), particularly in flat regions. In contrast, the sparse and medium forest patches were more prevalent.

Furthermore, other non-forest land cover types were more significant with an approximately coverage of $20 \%$. The 
dense forest cover was merely $20 \%$ between elevations of $201 \mathrm{~m}$ to $400 \mathrm{~m}$. However, the coverage increased rapidly to a maximum of nearly $86 \%$ between $801 \mathrm{~m}$ and $1,000 \mathrm{~m}$ (and a slight decrease above this level). Based on the exiguous amount of pixels at the high elevations, it is emphasized that changes in single pixels results in far reaching changes in percentages.
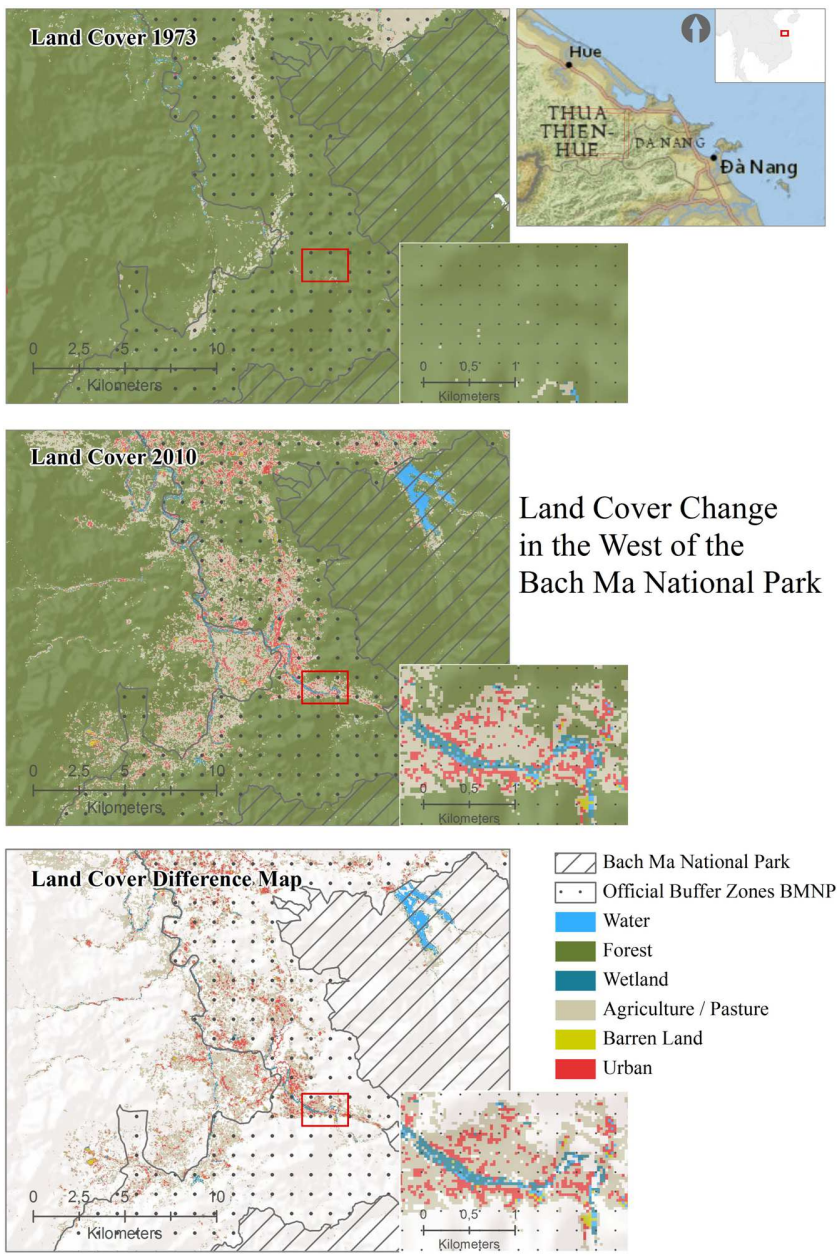

Figure 3. The land cover development within the western buffer zone of Bach Ma National Park between 1973 and 2010.

When analyzing the two official buffer zone regions, an elevation step from $1601 \mathrm{~m}$ to $1800 \mathrm{~m}$ needs to be added. At low elevations, the coverage of the dense forest is less than that within BMNP in 1973. The maximum coverage of $82 \%$ was reached between $801 \mathrm{~m}$ to $1,000 \mathrm{~m}$. Above this elevation, the dense forest cover decreased considerably. In 2000, the dense forest patches within the first elevation level $(0 \mathrm{~m}$ to $200 \mathrm{~m}$ ) nearly disappeared. Above $1,000 \mathrm{~m}$, the coverage reached nearly $100 \%$. This indicates a recovery of forest patches at high elevations. In 2010, the coverage of dense forest communities at the low elevations was remarkably small and reached only $\sim 12 \%$ between $201 \mathrm{~m}$ and $400 \mathrm{~m}$, but with an intensive increase above these elevations. The rising importance of the sparse forest patches and other land cover types may be a reason for the decreasing coverage of dense forests at low elevations.

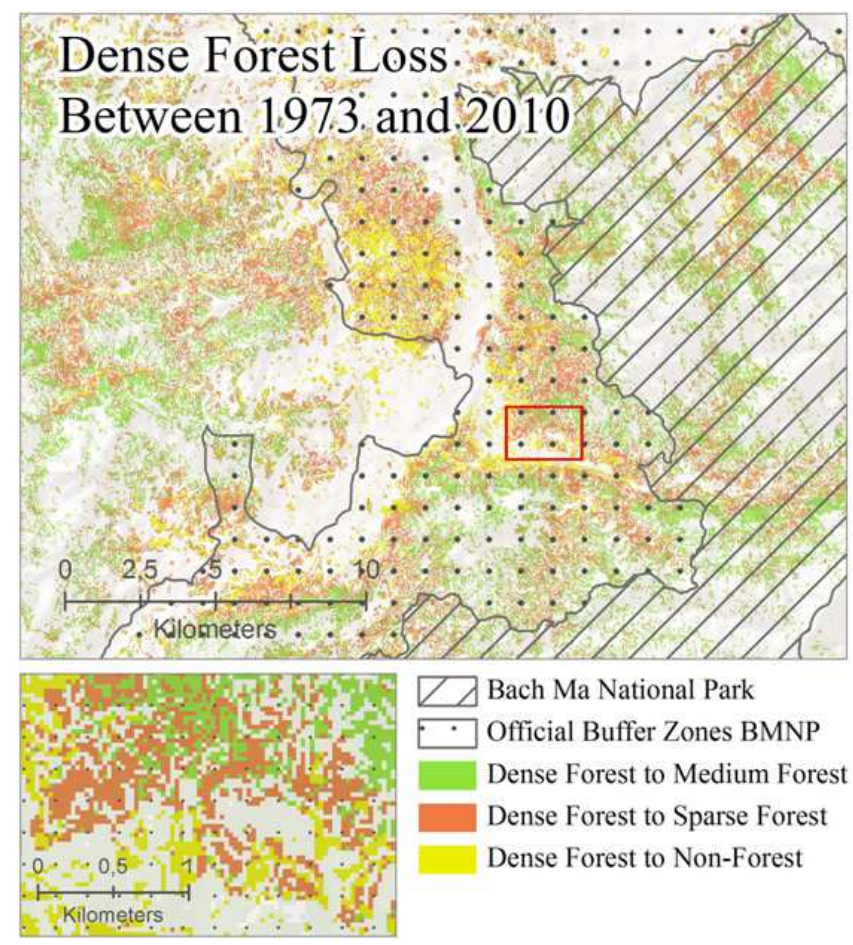

Figure 4. The loss of dense forest within the western buffer zone of Bach Ma National Park between 1973 and 2010.

In particular, the pasture and cropland areas have exhibited considerable growth. In 1973, at the $0-200 \mathrm{~m}$ elevations, approximately $22 \%$ of the buffer zones were covered with pasture and cropland. Between $201 \mathrm{~m}$ and $400 \mathrm{~m}$ elevations, only $2 \%$ of the area was used for these land cover classes in 1973. In 2010, the pasture and cropland covered more than $28 \%$ of the area at $0-200 \mathrm{~m}$ elevations, $11 \%$ at $201-400 \mathrm{~m}$, and $7 \%$ at $401-600 \mathrm{~m}$. This underlines the increased demand of cultivable land and the growing population. Additionally, the urban areas have occupied more land within the two buffer zones. The urban areas expanded from $0.5 \%$ in 1973 to $13.2 \%$ in 2000 . In 2010, a very high coverage of $9.3 \%$ was observed.

\section{Discussion}

The analyzed Landsat time series impressively illustrates the past land cover changes within BMNP and the adjacent areas. A distinct bisection between the national park and adjacent areas is observable. In the 1970s, the natural forest patches existed without major external influences. However, at high elevations, the coverage of the dense forest was astonishing low within and outside of the national park. A reason for this occurrence may be damage caused by the war in the 1970s and the use of Agent Orange. Furthermore, the local people migrated from the flat regions at higher elevations to safer and more secure locations [17,23]. In 1991, BMNP was officially designated and the forest cover decreased from $99.1 \%$ to $98 \%$ (or $98.3 \%$ to $94.3 \%$ in the former BMNP areal extent). Accompanying this declining coverage, the particularly dense forest patches were seriously affected and decreased at low elevations. This 
decline continued between 1989 and 2000. The forest coverage decreased from $98 \%$ to 93.7 (or $94.3 \%$ to $89.1 \%$ in the former BMNP areal extent). The dense forest communities were greatly affected and decreased considerably. These developments are associated with the historically low forest coverage of $24.7 \%$ over the entire country, detected in 1993 by the Forestry Inventory and Planning Institute of Vietnam [14]. In response to these crucial changes and the alarming decline of natural habitats, various national programs and projects of utmost importance were initiated (e.g., Five Million Hectare Reforestation Program; Strategy for a Protected Area System in Vietnam to 2010) [16]. Subsequently, the dense forest coverage only slightly decreased, where as the medium and sparse forest patches slightly increased. However, based on the statistics from 2000, the forest cover expanded in the former area of BMNP and the extension zone. Of particular interest are developments within the extension zone of the national park, which faces serious problems due to illegal logging activities leading to comprehensive forest degradation [19]. In 1973, the extension zone was completely covered by forest, including over three-quarters of dense forest. Major changes began after 1989: a decline of the dense forest patches and a growth of the medium and sparse forest communities were observed. Small sections of the region were used for pasture farming and cultivation, especially in 2000 and 2002. Based on various international projects (e.g., Green Corridor Project, CarBi Project) the loss of natural forest habitats was halted or slowed down considerably. The decline of the dense forest in combination with the historical low in $2005(56.9 \%)$ could be reversed by an increase of the dense forest $(60 \%$ in 2010$)$ for the extension zone. Nevertheless, compared with the conditions of 1989, notable natural dense forest patches were converted into medium and sparse forest patches.

Even more pervasive were land cover changes within the two official buffer zones of the national park. In 1973, the medium and sparse forest communities, along with other non-forest land cover types, constituted the majority of the land cover. The decrease of the dense forest patches could only be curtailed within the study period. At low elevations, especially $0-200 \mathrm{~m}$ and $201-400 \mathrm{~m}$, the dense forest patches and associated flora and fauna communities are nearly extinct. Therefore, forest communities within the national park are becoming more fragmented and isolated. This is associated with the decreasing resilience concerning environmental fluctuations $[43,44]$. The population growth and emerging towns of Nam Dong and Phu Loc have left their ecological footprints with an increasing impact on the region. Despite several infrastructure improvements (e.g., road construction) within these remote areas, the local people are still dependent on timber and NTFP to a large extent. Plantation forest (e.g., acacia and rubber), pasture farming and cropland are generally the most important income sources for the local people. These activities have an enormous impact on the land cover and structure within the buffer zones. With 79,000 people, the buffer zones are densely populated (137 people/ $\mathrm{km}^{2}$ ) [19]. The local people use available areas for agriculture and forest plantations, especially low elevation areas near streams.

Additionally, this study demonstrates that the Landsat time series are an appropriate data source to analyze land cover changes in and around protected areas. The limited spectral and spatial resolutions for the Landsat TM and ETM + and the revisit time of 16 days associated with prevalent cloud coverage in tropical regions reduce the scale of operations $[45,26]$. Several land cover classes could be discriminated with certain limitations for automatic procedures. For a time series with different phenological stages and intra-regional differences, the classification of natural and artificial forest patches becomes extremely complicated [46]. It is almost impossible to distinguish mixed forest patches with inner-regional and intra-seasonal fluctuations in dense, medium, sparse, restoration, and plantation forests simply on the basis of the NDVI [47]. The new Landsat 8 or Sentinel-2 satellites, each with ten spectral bands, offer more capabilities for future research $[48,49]$. However, important deforestation trends are easily detectable with the available Landsat images. Unfortunately, other important impact factors cannot be observed with the same accuracy [50]. The entire BMNP, especially the extension zone, is affected by illegal logging activities of single trees, hunting of selected and valuable species and exploitation of selected plant species (e.g., for medical use) $[18,19]$. For Landsat TM and ETM+ images, these small-scale disturbances are difficult to detect due to only slight decreases within the coverage [51]. Additional spectral bands are necessary to distinguish single tree species or certain associated groups. The projected 28-band WorldView-3 from DigitialGlobe or hyperspectral imaging (e.g., EnMAP) will encourage considerable progress towards detailed monitoring procedures.

\section{Conclusion}

Contrary to typical expectations, protected areas are not a panacea for global environmental problems. Despite their extensive networks and achievements within the last decades, global datasets and studies demonstrate the ongoing changes and degradation of natural ecosystems. Developing countries within the tropics bear the great responsibility of maintaining biodiversity hotspots. For a country like Vietnam, where the most fertile regions (i.e., the Mekong and Red River deltas or coastlines) are crowded with millions of people, the designation of a widespread network of efficient protected areas is even more complicated. Despite the large increase in protected areas and associated natural communities, protected areas are certainly not islands of felicity in Vietnam. The extinction of the wild Javan Rhino within Cat Tien National Park [52], the endangered Saola [53] and the Indochinese Tiger / Panthera tigris $[23,54]$ demonstrate that the existing network and management are still too weak. Additionally, this study illustrates that the land cover conflicts are often shifted 
directly outside of the protected areas. A sparse population within a protected area is often deemed more problematic than a dense population close to the border of the protected area. Certainly, where access is based on low elevations or a convenient river system, cross border impacts from local people is observed. In remote areas, the timber and NTFP are still the most important income sources for local residents. Additionally, historical land use practices carried out by local people on small scales become illegal due to the regulations of the protected area. If alternative sources of income are lacking, people are forced to act illegally to ensure their survival. The current pilot policy on benefit sharing (decision 126/QD-TTg), permits local people to extract selected forest products [55]. This could be a possible provisional solution and has to be monitored.

Therefore, protected areas and associated organizations should concentrate not only on the conservation of their bordered territory but also on the adjacent areas and the livelihood of the local people. This is particularly relevant, when such strictly protected areas such as national parks or strict nature reserves contain appropriate instruments to achieve such comprehensive goals. Based on these needs, the concept of the biosphere reserve was created. These model regions are established all over the world to reconcile natural, economic and social issues with local stakeholders. The distribution in core zones, buffer zones, and transition zones fosters the understanding and acceptance concerning the various objectives and goals of each zone. An integration of the various protected areas (e.g., BMNP, Saola Nature Reserves, Xe Xap National Biodiversity Conservation Area) within the regions of Central Vietnam and the Annamite Mountains as a biosphere reserve could create a more powerful network of protected areas in Vietnam and Laos. The reserve would combine strict protected areas with diverse zones of economic objectives. Finally, it would be a step toward the ultimate goal of safeguarding the only remaining green transect between the southeastern sea and the Annamite Mountain, which would be in line with the original purpose of BMNP.

\section{Acknowledgements}

Thanks are due to project partners and colleagues for their continuous support and assistance. With special thanks to the State Graduate Sponsorship Program of the federal state Mecklenburg-Vorpommern (Germany) for financial support.

\section{References}

[1] Bundesamt für Naturschutz (BfN), "Hintergrundinfo: 100 Jahre Naturschutz als Staatsaufgabe (1906 - 2006)“, 2006, Bonn.

[2] S. Chape, J. Harrison, M. Spalding, I. Lysenko, "Measuring the extent and effectiveness of protected areas as an indicator for meeting global biodiversity targets," Philosophical Transactions of the Royal Society B: Biological Sciences, vol. 360, pp.443-455, 2005
[3] M. R. W. Rands, W. M. Adams, L. Bennun, S. H. M. Butchart, A. Clements, D. Coomes, A. Entwistle, I. Hodge, V. Kapos, J. P. W. Scharlemann, W. J. Sutherland, and B. Vira, "Biodiversity Conservation: Challenges Beyond 2010," Science 329, pp. 1298-1303, 2010.

[4] World Database on Protected Areas (WDPA), "National stats for 1990-2012 from the 2013 MDG analysis," http://www.wdpa.org/Statistics.aspx., Accessed 15 October 2013.

[5] T. H. Ricketts, E. Dinerstein, T. Boucher, T. M. Brooks, S. H. M. Butchart, M. Hoffmann, J. F. Lamoreux, J. Morrison, M. Parr, J. D. Pilgrim, A. S. Rodrigues, W. Sechrest, G. E. Wallace, K. Berlin, J. Bielby, N. D. Burgess, D. R. Church, N. Cox, D. Knox, C. Loucks, G. W. Luck, L. L. Master, R. Moore, R. Naidoo, R. Ridgely, G. E. Schatz, G. Shire, H. Strand, W. Wettengel, and E. Wikramanayake, "Pinpointing and preventing imminent extinctions," Proceedings of the National Academy of Sciences of the United States of America, vol. 102, pp. 18497-18501, 2005.

[6] F. Achard, H. D. Eva, H.-J. Stibig, P. Mayaux, J. Gallego, T. Richards, and J.-P. Malingreau, "Determination of Deforestation Rates of the World's Humid Tropical Forest," Science, vol. 297, pp. 999-1002, 2002.

[7] D. C. Duro, N. C. Coops, M. A. Wulder, and T. Han, "Development of a large area biodiversity monitoring system driven by remote sensing," Progress in Physical Geography vol. 31, pp. 235-260, 2007.

[8] S. Schindler, H. von Wehrden, K. Poirazidis, T. Wrbka, and V. Kati, "Multiscale performance of landscape metrics as indicators of species richness of plants, insects and vertebrates," Ecological Indicators, vol. 31, pp. 41-48, 2013.

[9] N. G. Yoccoz, J. D. Nichols, and T. Boulinier, "Monitoring of biological diversity in space and time," Trends in Ecology \& Evolution, vol. 16, pp. 446-453, 2001.

[10] S. H. M. Butchart, M. Walpole, B. Collen, A. van Strien, J. P. W. Scharlemann, R. E. A. Almond, J. E. M. Baillie, B. Bomhard, C. Brown, J. Bruno, K. E. Carpenter, G. M. Carr, J. Chanson, A. M. Chenery, J. Csirke, N. C. Davidson, F. Dentener, M. Foster, A. Galli, J. N. Galloway, P. Genovesi, R. D. Gregory, M. Hockings, V. Kapos, J.-F. Lamarque, F. Leverington, J. Loh, M. A. McGeoch, L. McRae, A. Minasyan, M. H. Morcillo, T. E. E. Oldfield, D. Pauly, S. Quader, C. Revenga, J. R. Sauer, B. Skolnik, D. Spear, D. Stanwell-Smith, S. N. Stuart, A. Symes, M. Tierney, T. D. Tyrrell, J.-C. Vie, and R. Watson, "Global Biodiversity: Indicators of Recent Declines," Science, vol. 328, pp. 1164-1168, 2010.

[11] P. McElwee, "Parks or People: Exploring alternative explanations for protected areas development in Viet Nam," in Workshop for Conservation and Sustainable Development - Comparative Perspectives, 2001.

[12] G. Rambaldi, S. Bugna, and M. Geiger, "Review of the Protected Area System of Vietnam," Asean Biodiversity, vol. 1, pp. 43-51, 2001.

[13] Ministry of Agriculture and Rural Development, National Programme of Vietnam on Monitoring, Assessment, and Reporting on Forests under the Project: Strengthening Monitoring, Assessment, and Reporting on Sustainable Forest Management in Asia (GCP/INT/988/JPN), 2009. 
[14] P. Meyfroidt and E. F. Lambin, "Forest transition in Vietnam and its environmental impacts," Global Change Biology, vol. 14, pp. 1319-1336, 2008.

[15] Birdlife International, "Updated draft list of protected areas in Vietnam” from 2012, unpublished.

[16] S. Bremer, "Schutzgebietsmanagement in Vietnam - eine Herausforderung für die Entwicklungszusammenarbeit," Forum Geoökologie, vol. 2, pp. 12-18, 2008.

[17] D. A. Gilmour and N. van San, Buffer Zone Management in Vietnam, IUCN, 1999.

[18] T. Thien An and S. Ziegler, "Utilization of medicinal plants in Bach Ma National Park, Vietnam," Medicinal Plant Conservation, vol. 7, pp. 3-5, 2001.

[19] N. V. Linh, Rapid Assessment of Carbon Stock in Bach Ma National Park, Thua Thien Hue Province, 2010.

[20] T. Geissmann, H. Trinh Dinh, T. La Quang, and L. Tallents, "A brief survey for crested gibbons in Bach Ma National Park, central Vietnam," Gibbon Journal, vol. 3, pp. 43-49, 2007.

[21] M. Waibel, Vietnam - A Tourism Tiger? Ausgewählte Aspekte der jüngeren touristischen Entwicklung Vietnams. Göttinger Schriften $\mathrm{zu}$ Landschaftsinterpretation und Tourismus Band 2, 2004.

[22] T. D. Vien and K. Fahrney, "An Overview of the Midlands of Vinh Phu Province," in Red Books, Green Hills. The Impact of Economic Reform on Restoration Ecology in the Midlands of Northern Vietnam, edited by T. Le Cuc, A. T. Rambo, K. Fahrney, T. D. Vien, J. Romm, and D. T. Sy, 1996, pp. 3-22.

[23] P. Yen, S. Ziegler, F. Huettmann, and A. I. Onyeahialam, "Change detection of forest and habitat resources from 1973 to 2001 in Bach Ma National Park, Vietnam, using remote sensing imagery," International Forestry Review, vol. 7, pp. $1-8,2005$.

[24] R. S. DeFries, R. A. Houghton, M. C. Hansen, C. B. Field, D. Skole, and J. R. G. Townshend, "Carbon emissions from tropical deforestation and regrowth based on satellite observations for the 1980s and 1990s," Proceedings of the National Academy of Sciences of the United States of America, vol. 22, pp. 14256-14261, 2002.

[25] J.-F. Mas, "Assessing protected area effectiveness using surrounding (buffer) areas environmentally similar to the target area," Environmental Monitoring and Assessment, vol. 105, pp. 69-80, 2005.

[26] K. Wang, S. E. Franklin, X. Guo, Y. He, and G. J. McDermid, "Problems in remote sensing of landscapes and habitats," Progress in Physical Geography, vol. 33, pp. 747-768, 2009.

[27] R. G. Congalton, "A Review of Assessing the Accuracy of Classifications of Remotely Sensed Data," Remote Sensing of Environment, vol. 37, pp. 35-46, 1991.

[28] G. M. Foody, "Status of land cover classification accuracy assessment," Remote Sensing of Environment, vol. 80, pp. 185-201, 2002

[29] T. A. Schroeder, W. B. Cohen, C. Song, M. J. Canty, and Z. Yang, "Radiometric correction of multi-temporal Landsat data for characterization of early successional forest patterns in western Oregon," Remote Sensing of Environment, vol. 103 , pp. 16-26, 2006.
[30] C. Song, C. E. Woodcock, K. C. Seto, M. P. Lenney, and S. A. Macomber, "Classification and Change Detection Using Landsat TM Data: When and How to Correct Atmospheric Effects?," Remote Sensing of Environment, vol. 75, pp. 230-244, 2001.

[31] J. R. Schott, C. Salvaggio, and W. J. Volchok, "Radiometric scene normalization using pseudoinvarant features," Remote Sensing of Environment, vol. 26, pp. 1-16, 1988.

[32] M. J. Canty and A. A. Nielsen, "Automatic radiometric normalization of multitemporal satellite imagery with the iteratively re-weighted MAD transformation," Remote Sensing of Environment, vol. 112, pp. 1025-1036, 2008.

[33] M. J. Canty, A. A. Nielsen, and M. Schmidt, "Automatic radiometric normalization of multitemporal satellite imagery," Remote Sensing of Environment, vol. 91, pp. 441-451, 2004

[34] A. Singh, "Digital change detection techniques using remotely-sensed data," International Journal of Remote Sensing, vol. 10, pp. 989-1003, 1989.

[35] T. Fung and E. LeDrew, "Application of Principal Component Analysis to Change Detection," Photogrammetric Engineering \& Remote Sensing, vol. 53, pp. 1649-1658, 1987.

[36] J. P. Guerschman, J. M. Paruelo, C. Di Bella, M. C. Giallorenzi, and F. Pacin, "Land cover classification in the Argentine Pampas using multi-temporal Landsat TM data," International Journal of Remote Sensing, vol. 24, pp. 3381-3402, 2003.

[37] D. Lu, P. Mausel, E. Brondízio, and Moran E., "Change detection techniques," International Journal of Remote Sensing, vol. 25, pp. 2365-2407, 2004.

[38] J. Otukei and T. Blaschke, "Land cover change assessment using decision trees, support vector machines and maximum likelihood classification algorithms," International Journal of Applied Earth Observation and Geoinformation, vol. 12, pp. 27-33, 2010

[39] B. Tso and P. M. Mather, Classification Methods For Remotely Sensed Data, 2nd ed., Taylor \& Francis, Boca Raton, London, New York, 2009.

[40] S. E. Franklin and M. A. Wulder, "Remote sensing methods in medium spatial resolution satellite data land cover classification of large areas," Progress in Physical Geography, vol. 26, pp. 173-205, 2002.

[41] D. Lu and Q. Weng, "A survey of image classification methods and techniques for improving classification performance," International Journal of Remote Sensing, vol. 28, pp. 823-870, 2007.

[42] T. W. Gillespie, G. M. Foody, D. Rocchini, A. P. Giorgi, and S Saatchi, "Measuring and modelling biodiversity from space," Progress in Physical Geography, vol. 32, pp. 203-221, 2008.

[43] F. S. Chapin III, E. S. Zavaleta, V. T. Eviner, R. L. Naylor, P. M. Vitousek, H. L. Reynolds, D. U. Hooper, S. Lavorel, O. E. Sala, S. E. Hobbie, M. C. Mack, and S. Díaz, "Consequences of changing biodiversity," Nature, vol. 405, pp. 234-242, 2000.

[44] L. M. Curran, S. N. Trigg, A. K. McDonald, D. Astiani, Y. M. Hardiono, P. Siregar, I. Caniago, and E. Kasischke, "Lowland Forest Loss in Protected Areas of Indonesian Borneo," Science, vol. 303, pp. 1000-1003, 2004. 
[45] G. P. Asner, "Cloud cover in Landsat observations of the Brazilian Amazon," International Journal of Remote Sensing, vol. 22, pp. 3855-3862, 2001.

[46] S. Lengyel, A. Kobler, L. Kutnar, E. Framstad, P.-Y. Henry, V. Babij, B. Gruber, D. Schmeller, and K. Henle, "A review and a framework for the integration of biodiversity monitoring at the habitat level," Biodivers Conserv vol. 17, pp. 3341-3356, 2008.

[47] N. Pettorelli, J. O. Vik, A. Mysterud, J.-M. Gaillard, C. J. Tucker, and N. C. Stenseth, "Using the satellite-derived NDVI to assess ecological responses to environmental change," Trends in Ecology \& Evolution, vol. 20, pp. 503-510, 2005

[48] W. J. Frampton, J. Dash, G. Watmough, and E. J. Milton, "Evaluating the capabilities of Sentinel-2 for quantitative estimation of biophysical variables in vegetation," ISPRS Journal of Photogrammetry and Remote Sensing, vol. 82, pp. 83-92, 2013.

[49] J. R. Irons, J. L. Dwyer, and J. A. Barsi, "The next Landsat satellite: The Landsat Data Continuity Mission," Remote Sensing of Environment, vol. 122, pp. 11-21, 2012.

[50] H. Nagendra, R. Lucas, J. P. Honrado, R. H. Jongman, C. Tarantino, M. Adamo, and P. Mairota, "Remote sensing for conservation monitoring: Assessing protected areas, habitat extent, habitat condition, species diversity, and threats," Ecological Indicators, vol. 33, pp. 45-59, 2013.

[51] G. P. Asner, M. Keller, R. Pereira, and J. C. Zweede, "Remote sensing of selective logging in Amazonia - Assessing limitations based on detailed field observations, Landsat ETM+, and textural analysis," Remote Sensing of Environment, vol. 80, pp. 483-496, 2002.

[52] TechMedia, "Vietnam Rhino Is Now Extinct, Officials Report," http://www.livescience.com/16744-vietnam-javanrhino-extinct.html., Accessed 15 October 2013, 2011.

[53] WWF, “Saola," http://wwf.panda.org/about_our_earth/ species/profiles/mammals/saola., Accessed 15 October 2013

[54] WWF, "Introducing the Indo-Chinese tiger (Panthera tigris corbetti),"

http://wwf.panda.org/what_we_do/where_we_work/project/ projects_in_depth/greater_annamites_ecoregion/publication/ ?22876/introducing-the-indo-chinese -tiger-ipanthera-tigris-corbettii., Accessed 15 October 2013

[55] The Socialist Republic of Vietnam, "Pilot policy on benefit sharing mechanism (BSM) in management, protection and development of special-use forests (SUFs)," 126/QD-TTg, 2012 